\title{
First report of white mould caused by Sclerotinia sclerotiorum on pea in Bangladesh
}

\author{
Md. Rabiul Islam ${ }^{1} \cdot$ Ananya Prova $^{2} \cdot$ Abdul Mannan Akanda $^{1} \cdot$ Md. Motaher Hossain $^{1}$ (D)
}

Received: 10 October 2019 / Accepted: 30 January 2020 / Published online: 10 February 2020

(C) Società Italiana di Patologia Vegetale (S.I.Pa.V.) 2020

Keywords Blighted stems and pods $\cdot$ Disease severity $\cdot$ Dark sclerotia $\cdot$ White appressed mycelia $\cdot$ Necrotic lesions

Pea (Pisum sativum L.) is one of the important winter-season legume crops in Bangladesh. In January 2018, farmers' fields in Chapainawabganj district were surveyed for pea diseases. Tan to light brown blighted stems and pods were detected in $2.6 \%$ of plants with an average disease severity rating of 3.7 (Little and Hills 1978). Prominent dark sclerotia (3.5-14.8 $\times$ $1.9-5.3 \mathrm{~mm}$ ) were found on the surface of the infected tissues or were embedded within the tissues. Surface-sterilized symptomatic tissues were placed on potato dextrose agar (PDA) and incubated at $25^{\circ} \mathrm{C}$ for 4 days. A white appressed mycelial growth radiated over the entire plate, with a ring of sclerotia forming on the edge of the plate by 7 days. Pathogenicity of the isolate was tested on 3-week-old pea plants (cv. BARI Motor shuti-3) by placing a mycelial plug of the fungus onto the superficially wounded stem above the soil (Prova et al. 2018). Plants were incubated in a moist chamber for 2 days prior to being transferred to a greenhouse. Necrotic lesions appeared on the stems by $4-5$ days after inoculation. The pathogen was re-isolated and the re-isolated fungal cultures appeared morphologically to be Sclerotinia sclerotiorum (Lib.) de Bary. Identification of the fungus was further confirmed by extracting DNA from the mycelium of three

Md. Motaher Hossain

hossainmm@bsmrau.edu.bd

Md. Rabiul Islam

rabiulislam2949@gmail.com

Ananya Prova

ananyaprova@gmail.com

Abdul Mannan Akanda

amakanda06@yahoo.com

1 Department of Plant Pathology, Bangabandhu Sheikh Mujibur Rahman Agricultural University, Gazipur 1706, Bangladesh

2 Department of Plant Pathology, EXIM Bank Agricultural University, Chapainawabganj 6300, Bangladesh representative cultures. The DNA samples were subjected to PCR using ITS (ITS4, 5'-TCCTCCGCTTATTGATATGC-3'; ITS1, 5'- TCCGTAGGTGAACC TGCGG-3') primers, which produced 572-bp amplicons that were purified and sequenced using the same primers (Prova et al. 2017). The best BLAST hits for the ITS region (GenBank accession No. MN216247) had $100 \%$ identity to strains of $S$. sclerotiorum. In Bangladesh, S. sclerotiorum has been found on different hosts (Prova et al. 2018) but, to our knowledge, this is the first evidence of pea infection in the field.

\section{References}

Little TM, Hills FJ (1978) Agricultural Experimental Design and Analysis. Wiley, New York

Prova A, Akanda MAM, Islam S, Hossain MM (2017) First report of Sclerotinia sclerotiorum causing pod rot disease on okra in Bangladesh. Can J Plant Pathol 39:72-76

Prova A, Akanda AM, Islam S, Hossain MM (2018) Characterization of Sclerotinia sclerotiorum, an emerging fungal pathogen causing blight in hyacinth bean (Lablab purpureus). Plant Pathol J 34:367

Publisher's note Springer Nature remains neutral with regard to jurisdictional claims in published maps and institutional affiliations. 